\title{
Analysis of School Strategic Planning Practices
}

\author{
Fransiskus Z. M. Deidhae ${ }^{1}$, Masrukhi ${ }^{2}$, Wahyu Hardyanto ${ }^{2}$, Fathur Rokhman ${ }^{2}$ \\ ${ }^{1}$ Lecturer, Sekolah Tinggi Pastoral Atma ReksaEnde, East Nusa Tenggara, Indonesia \\ ${ }^{2}$ Professor, Education Management Department, Semarang State University, Indonesia
}

Corresponding Author: Fransiskus Z. M. Deidhae

\begin{abstract}
Public sectors in Indonesia have begun to implement strategic planning since the decade of the 2000s, in line with the decentralization policy in education sector. This qualitative descriptive study examined Senior High School strategic planning documents and confirmed the documents through interviews. The study aims to identify models used and its formulation in annual school plan. The result shows that many private schools do not have strategic planning yet. The models used are issue-based models offered by the ministry of national education with variation of components of planning and employment of two main instruments: SWOT and gap analysis. All schools having strategic planning formulate them in the annual work plan, however, not all of school implement them consistently.
\end{abstract}

Keywords: instrument analysis, gap, SWOT, model, strategic planning

\section{INTRODUCTION}

Strategic planning originating from business has become a part of the public and education sector. Since the decade of the 1980s, schools have adopted strategic planning. Regardless of pros and cons of its adoption in education sector, strategic planning has become the part of education until now. Public believes that implementation of strategic planning puts schools on a pathway of development to make rapid and directed changes to education.

In Indonesia, strategic planning adoption in education comes from a background of the decentralization policy.
The decentralization policy is legally actualized in the form of two important rules namely Law Number 22 of 1999 on regional government and Law Number 25 of 1999 on financial balance between central and local government. Both laws transfer some of the authority from the center to regions. Therefore, it provides greater autonomy to regional government. The decentralization policy, that believed to make faster changes, covers several sectors including education and health (Mulyasa, 2017: 12-14).

In public sector, Indonesian government, in Law Number 25 of 2004 that further elaborated into Government Regulation Number 40 of 2006, requires all ministries or public institutions to draw up the strategic plan referring to initial draft of the Medium-Term National Development Plan. Meanwhile, in education sector, the government does not formally require primary and secondary schools to have the strategic plan. The ministry of national education implicitly requires schools to have school plans to fulfill management standard in accordance with Law Number 3 of 2003 on national education system and Governmental Regulations of the Republic of Indonesia Number 19 of 2005 on national education standard. According to Education Management Standard, every school is obliged to have the annual plan including visions, missions, goals, and plan of activities. The annual work plan is the basis for school management based on principles of independence, partnership, participation, openness, and accountability (Governmental 
Regulation Number 19 of 2007, attachment A point 4.d).

In addition to the regulations, the Ministry of National Education published Technical Instructions for Senior High School Work Plans (2010) and the School Principal Work Guide (2017) that contains guidelines for the preparation of strategic plans or medium-term work plans. The technical instructions present medium-term planning model including components similar to the strategic plan, i.e. visions, missions, goal, objectives, gap analysis and strengths, weaknesses, opportunities, and threats (SWOT) analysis, strategies, and implementation and evaluation plans.

Discourses and practices of school planning has been going on for more than a decade and has been practiced in all schools including in Ende Regency, East Nusa Tenggara Province, that is approximately 1700 kilometers away from the capital city, Jakarta. Long distance to the expanse of the archipelago shows how far it is from the development center, limited access to information, and lagged behind in human resource quality. Those gaps trigger researchers to study on how is the practice of strategic planning in Senior High Schools in Ende Regency. The practice includes the most common used model of strategic planning and its implementation. In the model identification, this study observes processes, analysis instruments used, strategic planning components, and stakeholder participations. Meanwhile, the model implementation is observed in annual work plan documents, mid-term plan documents, and annual evaluation reports.

\section{LITERATURE REVIEW}

Strategic planning is the part of strategic management consisting three steps of planning, implementation, and control. The following definitions clearly delineate the meaning of strategic planning. Bryson (2014: 7-8) defines strategic planning as "a deliberative, disciplined, approach to producing fundamental decisions and actions that shape and guide what an organization (or another entity) is, what it does, and why". Meanwhile, Andersen (2004: 1275) defines strategic planning processes as "organizational activities that systematically discuss mission and goals, explore the competitive environment, analyze strategic alternatives, and coordinate actions of implementation across the entire organization". Both cited definitions implicitly describe that strategic planning is (1) a rational action relying on data accuracy, analysis, and synthesis to determine a framework for actions, (2) issue identification or key problem influencing organizations now and in the future, (3) direction determination to be achieved in the form of missions, visions, goals and (4) framework determination to act in strategies, programs, action plans, and evaluation plans to achieve conditions desired by organizations (Andersen, 2004; Bryson, 2011: 8).

In the model framework, those elements of the definitions refer to an issuebased strategic planning model. McNamara (2006) categorizes strategic planning into five models i.e. basic model, alignment model, scenario model, organic model, and issue-based or goal-based model. According to McNamara (2011) and David \& David (2015: 47), the most common model used in all types of organizations is issue-based model because it is considered the most comprehensive. Although it does not provide a guarantee for success, this model provides a clear and practical approach to strategy formulation, implementation, and evaluation. Stages of issue-based model according to McNamara (2006) are as follows:

1. Asses external/internal factors to identify strengths, weaknesses, opportunities, and threats

2. Identify and prioritize major issues/goals

3. Design major strategies (or programs) to address issues/goals

4. Design/update vision, mission and values 
5. Establish action plans (objectives, resource needs, roles and responsibilities for implementation)

6. Record issues, goals, strategies/ programs, updated mission and vision, and action plans in a strategic plan document

7. Develop the yearly operating plan document (from year one of the multiyear strategic plan)

8. Develop and authorize budget for year one (allocation of funds needed to fund year one)

9. Conduct the organization's year-one operations

10. Monitor/review/evaluate/update strategic plan document

Some experts in education such as Lerner (1999) Lane, Bishop, \& Jones (2013), Pisel (2014) have offered issuedbased model with additional variations or changes in particular stage arrangement.
1. Lerner (1999) proposes a conceptual model of specific strategic planning for California State University with four main stages.

2. Lane, Bishop, \& Jones (2013) suggest a conceptual model of strategic planning for public schools in USA. There are 19 stages proposed that are categorized into five important stages namely, preparation, direction determination, environment analysis, goal settings, and action planning.

3. Pisel (2014) recommends a hypothetical model for distance learning in America with ten stages similar to issue-based model described by McNamara.

4. In Indonesia, Ministry of Education and Culture (2017: 14-16) proposes medium-term planning model with nine development stages.

The following table shows a comparison of the above models.

Table 1:Comparison of Strategic Planning Models in Education.

\begin{tabular}{|c|c|c|c|}
\hline Model & Process & Characteristic & Weakness \\
\hline $\begin{array}{l}\text { Lerner, } \\
1999\end{array}$ & $\begin{array}{l}\text { 1. Vision and mission formulation, } \\
\text { 2. environmental analysis: SWOT, } \\
\text { 3. gap,benchmarking } \\
\text { 4. Program determination } \\
\text { 5. Setting goals, action plans, tactics } \\
\text { 6. }\end{array}$ & $\begin{array}{l}\text { 1. Vision and mission are } \\
\text { set in initial stage. } \\
\text { 2. Three analytical } \\
\text { instruments are used. }\end{array}$ & $\begin{array}{l}\text { 1. The model does } \\
\text { not state } \\
\text { objectives } \\
\text { analysis clearly; } \\
\text { 2. Combination of } 3 \\
\text { instruments in } \\
\text { determining } \\
\text { strategy is not } \\
\text { explained in } \\
\text { detail. }\end{array}$ \\
\hline $\begin{array}{l}\text { Lane } \\
\text { et al., } 2013\end{array}$ & $\begin{array}{l}\text { 1. Preparation: (stage 1-8) obtain supports from stakeholders } \\
\text { and build mutual understanding through explanation } \\
\text { process } \\
\text { 2. Direction determination in education in the form of } \\
\text { visions and missions (stage 9). } \\
\text { 3. Environmental analysis by using SWOT and determining } \\
\text { planning areas (stage 10,11,12,18, and 19) } \\
\text { 4. Setting goals and target (stage 13-14) } \\
\text { 5. Formulate action plans (activities, scheduling, budget, } \\
\text { analysis for implementation - stage } 15 \text { to } 17 \text { ). }\end{array}$ & $\begin{array}{l}\text { 1. } \begin{array}{l}\text { Long preparation } \\
\text { process to create } \\
\text { understanding; }\end{array} \\
\text { 2. Visions and missions } \\
\text { are set in the first } \\
\text { stage; } \\
\text { 3. Strategy formulation is } \\
\text { replaced with planning } \\
\text { area; } \\
\text { There is analysis } \\
\text { process for } \\
\text { implementation. f }\end{array}$ & $\begin{array}{l}\text { 1. Long processes } \\
\text { in creating } \\
\text { understanding } \\
\text { and commitment; } \\
\text { 2. The model does } \\
\text { not explain set of } \\
\text { goals and action } \\
\text { plans in detail. }\end{array}$ \\
\hline Pisel, 2014 & $\begin{array}{l}\text { 1. Preparation: decisions for planning, resource assessment, } \\
\text { and building a work team } \\
\text { 2. Requirements and scheduling } \\
\text { 3. Environmental analysis (SWOT) and necessity/gap } \\
\text { analysis } \\
\text { 4. Reviewing institution visions } \\
\text { 5. Assumption formulation, a kind of hypothesis about } \\
\text { current and future conditions } \\
\text { 6. Development of strategies and series of activities } \\
\text { 7. Functional analysis: comparing strategy with existing } \\
\text { policies and resources } \\
\text { 8mplementation: distribution of duties and } \\
\text { responsibilities, and allocation of funds, personnel, and } \\
\text { various other assets } \\
\text { Conducting assessment: summative and formative } \\
\text { 10. Review the planning and implementation periodically. }\end{array}$ & $\begin{array}{l}\text { 1. Detailed preparation } \\
\text { stages } \\
\text { 2. Specific stages to } \\
\text { determine } \\
\text { assumptions, } \\
\text { functional analysis, } \\
\text { and assessment for } \\
\text { implementation. }\end{array}$ & $\begin{array}{l}\text { 1. The analysis of } \\
\text { objectives } \\
\text { (vision, goals, } \\
\text { and objectives) } \\
\text { are not explained } \\
\text { in detail. }\end{array}$ \\
\hline
\end{tabular}




\begin{tabular}{|c|c|c|c|c|c|}
\hline \multicolumn{6}{|c|}{ Table no 1.continued..... } \\
\hline $\begin{array}{l}\text { Ministry of } \\
\text { Education } \\
\text { and Culture } \\
\text { of } \\
\text { Indonesia, } \\
2017\end{array}$ & & $\begin{array}{l}\text { Formulate schools' visions, missions, and goals. } \\
\text { Environmental analysis using SWOT and school self- } \\
\text { evaluation. } \\
\text { Conduct internal analysis using National Education } \\
\text { Standards indicators. } \\
\text { Find gaps between real conditions and ideal conditions. } \\
\text { Gaps in each indicator become reference material for } \\
\text { strategy formulation. } \\
\text { Categorize school programs detected from gaps based on } \\
\text { a priority scale. } \\
\text { Make priority scale into medium-term work plan. } \\
\text { Describe strategies into the annual activities. } \\
\text { Design complete annual plan: time schedule, those } \\
\text { responsible, and budget. } \\
\text { Planfor monitoring and evaluation process. }\end{array}$ & 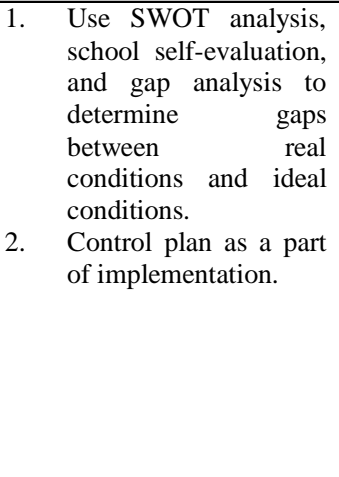 & & $\begin{array}{l}\text { Visions, } \\
\text { missions, and } \\
\text { goals are not an } \\
\text { integral part of } \\
\text { the process. } \\
\text { There is no } \\
\text { objectives } \\
\text { analysis (visions, } \\
\text { goals, and } \\
\text { objectives). }\end{array}$ \\
\hline
\end{tabular}

Aside from the models, strategic planning applies several analytical instruments or tools. David \& David (2015:257) describe nine matrix analysis commonly used in business as series of tools that must be used to formulate strategic decisions. The nine matrices are internal factor evaluation matrix (IFE), external factor evaluation matrix (EFE), competitive profile matrix (CPM), SWOT analysis, strategic position and action evaluation (SPACE), Boston Consulting Group (BCG), internal-external matrix (IE), grand strategy, and quantitative strategic planning matrix (QSPM).

In education sector, several researchers conclude that SWOT is the most widely used instrument since it is more practical in drawing strategies (Hai \& Tsou,2009; Helms \& Nixon, 2010; Kuiper \& Thomas, 2000; Syahrul, 2017). Several studies in Indonesia also underline the same finding that SWOT is the most common used in public institutions since it is more applicable (Susanto, 2005; Masakin 2012; Amin 2016; Syahrul, 2017; Restusari, 2017). However, SWOT analysis has a number of weaknesses, such as relying on subjective intuition, not being systematic, quantification that has many biases, and lacks predictive power (Fleisher \& Bensoussan, 2002).

Each model and instrument have strengths and weaknesses. Therefore, each organization should modify existing models and adjust them to the unique needs and situations of the organization (McNamara, 2006). According to Schraeder (2002) and
Linn (2008), strategic planning does not have to follow a long and complicated process. Simple and short models can be an option. The most important part of strategic plan is its ability to respond to rapidly changing external situations, determine strategies, and mobilize actions of all stakeholders in education to achieve common goals.

Several previous studies have shown that strategic planning has positive impacts on school performances and climates (Lumby, 1999; Musnandar, 2013). Some studies at several senior high schools and universities in Indonesia show that the schools have implemented strategic planning effectively (Kamayuda \& Krismanda, 2016; Syahrul 2017), by formulating differentiation strategies to improve school qualities (Susanto, 2005), and even aggressive strategic planning with diverse programs (Ni Luh, 2013).

A survey conducted by Amin (2016) on senior high school principals in Serang Regency, Banten, shows that school principals have implemented strategic management activities to mobilize teachers and education personnel to achieve school goals. However, the result indicates the level of its implementation varies: 7 (14\%) respondents are below the average or less effective group, 27 (54\%) respondents are in the average or effective group, and 16 $(32 \%)$ respondents are above the average or very effective group.

Although schools have implemented strategic planning, result of the studies record several weaknesses in the process. 
Those weaknesses refer to SWOT analysis that is not based on accurate data (Musnandar, 2013; Syahrul, 2017), and is not able to create alternative strategies (Hayati\& Unik, 2008); the process does not involve all the school stakeholders and does not lead to both strategic issues and policies (Masakim, Nizwardi, \& Fahmi, 2012; Syahrul, 2017); there is no competitive strategies for school development (Kamayuda \& Krismanda, 2016), and strategic planning is done more than just to fulfill administrative demands and become a trend because it is not implemented consistently (Syahrul, 2017; Masakim, Nizwardi, \& Fahmi (2012).

Wyk \& Moeng (2014) shows that collaborative approach between principals, teachers, and managers in strategic planning require the school to develop consultative, inclusive, and coherent planning processes. In a collaborative process, school community can arrange strategic planning with their own ways, but still refers to general aspects supporting the whole process. The researchers conclude that school strategic planning should have three main elements, i.e. strategic analysis involving all stakeholders, strategic choices determining the direction (priorities, missions, and visions), and strategies to act.

\section{RESEARCH METHOD}

This study employs inductive inquiry approach at 21 senior high schools in Ende Regency, East Nusa Tenggara, Indonesia. The regency is in central Flores Island with land area is about 946.20 square kilometers and most of the area is mountainous. The number of population of the regency claim up to 270,763 . There are 21 senior high schools with 8,062 students and 16 vocational schools with number of 6,489 students (BPS, 2021: 73-77). This study focuses on the whole senior high schools in the regency and not the vocational schools.

As qualitative study, its characteristics emphasize the understanding of what is happening in participants' world and interpretation of evidences. Creswell (2007: 36) states that qualitative study prioritizes the process come from philosophical assumptions, worldviews, and theoretical perspectives to find the meaning imposed by individuals or social group on a problem or phenomena.

Another characteristic of qualitative study is that researchers are responsible for the entire process of data collection and analysis. They are involved in the whole process of data collection especially interviews in order to observe respondent's responses, capture the meaning written in words and implied in non-verbal expressions such as gestures and expressions. Thus, researchers are an important variable in the entire research process. To avoid subjective bias, they must do careful documentation during the process (Arce, 1998: 9-10). In addition to accurate documentation, qualitative research uses multiple methods to understand the phenomena deeper and one of the methods is triangulation (Flick, 2002 in Denzim \& Lincoln, 2005: 5). This study ensured the data credibility by source triangulation and data collection technique. The main data source originated from planning documents and school evaluation reports. For data confirmation, the researchers interviewed principals and vice principals of curriculum. If the data obtained is inadequate or contradictory, the researcher conducted the triangulation by interviewing other respondents selected from one of the teachers who knows the school strategic planning.

\section{RESULT}

Data collection in 21 senior high schools in Ende Regency shows that eight schools $(38.1 \%)$ do not yet have strategic plan and 13 others $(61.9 \%)$ have strategic plan with various models and processes. All schools do not have strategic plan are private schools while schools who have strategic plan are nine public schools $(42.9 \%)$ and four private schools (19\%). At the beginning of the interview, all schools 
reported to have strategic plan. However, after examining the documents, it turned out that the schools do not have medium-term program for three to five years and only have annual work plan. The schools only attach their visions and missions at the beginning of the annual plan and considered as strategic plan.

Strategic planning process generally involves stakeholders such as teachers, staff, representatives of committee and managing foundation. Four $(30.8 \%)$ out of 13 schools have the plan designed by special teams and in turn is socialized to teachers and employees. One school (7.7\%) has strategic plan arranged by the foundation and the school have further elaboration in the annual work plan, while eight schools (61.5\%) involve all stakeholders in the process.

Based on the instrument, all the schools use environmental analysis with both gap analysis and SWOT analysis instrument modified based on the understanding and skills owned. Eight schools (77.78\%) conduct internal environmental analysis by using gap analysis based on the criteria of eight educational standards set by Ministry of National Education and Culture. Meanwhile, five education units $(32.22 \%)$ use SWOT instrument integrated with gap analysis as the part of internal environmental analysis. However, in formulating the strategies, the schools do not refer to the four-quadrants of SWOT analysis but to the gap analysis. Thus, the strategy analysis used is based on the internal weaknesses and not based on external factors that influence the schools. By using the gap analysis, the schools apply in-out perspective in addressing their strategies and ignore the external environment.

Based on the model used, all the schools adopt issue-based model proposed by ministry of national education and modify it based on the understanding and local necessity. This model appears in the process and components owned. A school $(7.7 \%)$ has variety of model with more components including visions, missions, values, environmental analysis, strategies, objectives, targets, key performance indicators, programs, and activities. Meanwhile, 12 other schools (92.3\%) adopt general framework consisting of visions, missions, goal, objectives, environmental analysis, and programs further described in the school annual plan with the variety on finance, program, and infrastructure development, however, it does not formally include strategic formulation changes. There is no school that formulate the plan to control their strategic plan.

\section{DISCUSSION}

Various practices of strategic planning in Ende Regency relate to the rules enforcement and skills of the school leaders. Several previous studies (Masakim, Nizwardi, \& Fahmi, 2012; Musnandar, 2013; Syahrul, 2017)conclude the same finding that implementation of strategic planning relates to the skills of the principal as a local manager. Besides, control system from the authoritative board such as provincial education office or board of foundation can support the practice of strategic planning in schools.

Regulation of Minister of National Education Number 28 of 2010 states that a principal should have the principal certificate obtained from a special training session. The short training aims to increase the capacity of principals and provide legality of personal, managerial, entrepreneurial, supervisory, and social competences. One of the training materials guides principals to have skills in the school planning.

The public senior high schools apply this regulation consistently due to the prerequisite to be the school principal. In addition, the principal's performance in strategic management becomes criteria in the process of promoting career path. Meanwhile, private schools do not require the fulfillment to takes the training to be the principal. There are only two private schools $(18.9 \%)$ out of 11 schools having 
the training though it is not compulsory for them. It is not surprising that many private schools do not yet have school strategic plan.

In public schools, provincial education office demands regular performance reports including open, participatory, and accountable school planning. The schools have to upload and update the report regularly in the official website. With such mechanism, both national education ministry and provincial office can control the schools in implementing their strategic plan. Besides, in social manner, people consider public schools as favorite schools because the government ensures infrastructures, facilities, teachers, and staff. Meanwhile, private schools that only receive subsidies from the government have to collect money from students and allocate most of the funds for salaries. In this case, public schools should morally perform better, including the planning process to improve their quality.

Different planning practices indicate different understandings and skill levels. Many school leaders are still confused between strategic planning and school annual plans and do not implement strategic planning in accordance with the guidelines provided by the ministry of education. This weakness indicates that most of the school leaders lack of knowledge and skills in processing strategic planning (Wyk\& Moeng, 2014; Lingam, Lingam, \& Raghuwaiya, 2014; Amin, 2016). Eleven principals $(84.6 \%)$ admitted that they personally did not fully understand the strategic planning process. There are difficulties for schools to apply the models or templates offered by the education department. Many of them expressed that the most difficult part in the planning is to set strategies based on both internal and external environment analysis, and how to formulate the goals (vision, goal, and objectives). A private school, for instance, has more components in the strategic plan but not all the strategies and programs specified in the annual plan.
One of the various understanding indicators relates to the use of analysis instrument. All schools admitted to use both SWOT analysis and gap analysis instrument. However, in the strategic plan document, the analysis conduct only used gap analysis while SWOT analysis becomes an overview to portray the school profile. The schools determine strategies and programs based on the gap analysis that focuses on internal condition. Therefore, strategies and programs do not emerge from a comprehensive internal-external environmental analysis but problem based. With such analysis, the school can formulate many programs and have to prioritize them in their annual work plans.

Seven school principals $(53.8 \%)$ admitted that in the implementation process, schools often make adjustments, changing the activity plans set with new activities arising due to the situation demand. Many school leaders expressed that in the course of time, they have to align their plan with the arising needs and the resources of the school. The practice actually leads the alignment model that allows the school to fine-tune strategies with its goals and resources (McNamara, 2006). It is common for an organization to make changes in their plan but when the changes happen frequently, it indicates that the plan has not gone through a comprehensive analysis process.

Based on the result of annual evaluation, nine schools (69.2\%) implement strategic planning consistently in their annual plans, while four schools (30.8\%) design annual program that differ from the strategic plan. In the planning process, the four schools only involved the teacher and staff. Participation of the stakeholders provides a vehicle for school to engage in a dialogue to formulate certain goal. There are choices but the most important that school has to agree on the common needs of their students. Besides, the forum of the stakeholders becomes both moral support and control mechanism for the school to implement the plan (Lumby, 1999; Wyk \& 
Moeng, 2014; Syahrul, 2017). If the school does not involve the stakeholders most probably it will not implement the plan consistently.

Nine $(69.2 \%)$ out of 13 schools acknowledged that they did not involve the external stakeholders such as representatives of committee, alumni, and board of foundation. The practice relates to its background of the local tradition that all the decision drawn by those who has authority and higher social status. This elitist approach has been a custom and in common view, the leaders have responsibility to construct the plan and make decisions (Lingam, Lingam, \& Raghuwaiya, 2014). However, the implementation of school based management (SBM) and decentralization policy have brought some changes in the school climate in Ende Regency. Most of the school have shifted their planning practice by involving the stakeholders and diminished a top-down approach. Since the involvement of the stakeholders enhances their responsibility to the school as well as to motivate the school staff to implement the plan consistently.

\section{CONCLUSION}

After almost two decades, in terms of the implementation of strategic planning, there are eight education units $(38.1 \%)$ in Ende Regency do not have strategic plan. Schools having strategic planning adopt the model proposed by the ministry and adapt it based on condition and local understanding. Variety of implementation of planning model is related to levels of understanding, skills, leadership style in the schools as well as the rules enforcement by the education department. This variety of practices requires provincial education office which is autonomously responsible for managing secondary education, to regularly conduct the training session and ensure the school leaders to be more competent in carrying out the strategic planning in their school.

Acknowledgement: None

\section{Conflict of Interest: None}

\section{Source of Funding: None}

\section{REFERENCES}

1. Ali, A. Z., \& Hanoum, S. (2012). Perancangan dan Pengukuran Kinerja Rencana Strategis SMA Khadijah Dengan Metode Balanced Scorecard. Jurnal Teknik Pomits, 1(1), 1-6.

2. Amin, M. (2016). Impelementasi Manajemen Strategis Kepala Sekolah Menengah Pertama di Kabupaten Serang. Tarbawi. 2(02), 42-57.

3. Andersen, T. J. (2004). Integrating decentralized strategy making and strategic planning processes. Journal of Management Studies, 41(8), 1271-1299.

4. Arce, J. (1998). Qualitative Research Method. Manila: Ateneo de Manila University Press.

5. BPS Kabupaten Ende. (2021). Kabupaten Ende Dalam Angka. BPS: Ende

6. Bryson, M.J. (2011). Strategic Planning for Public and Nonprofit Organization. San Francisco: Jossey-Bass John Wiley \& Sons, Inc.

7. Crewell, W.J. 2007. Qualitativ Inquiriy and Research Design. Choosing among Five Approache. Thousand Oaks: Sage Publication.

8. David R. F. \& David, R. F. (2015). Strategic Management, Concept and Cases. Essex: Pearson.

9. Direktorat Pembinaan Sekolah Menengah Atas. (2010). Juknis Penyusunan Rencana Kerja Sekolah. Jakarta: Departemen Pendidikan dan Kebudayaan.

10. Direktorat Jenderal Guru Dan Tenaga Kependidikan, Direktorat Pembinaan Tenaga Kependidikan Pendidikan Dasar Dan Menengah (2017). Panduan Kerja Kepala Sekolah. Jakarta: Departemen Pendidikan dan Kebudayaan.

11. Denzin, K.N. \& Lincoln S.Y.(Eds). 2005. The Sage Handbook of qualitative Research. Thousand Oaks: Sage Publication.

12. Dooris, M. J. "Two decades of strategic planning a history of higher education strategic planning," Plan. High. Educ., vol. 31, no. 2, pp. 26-32, 2003, [Online]. Available:

http://www.opia.psu.edu/sites/default/files/t wodecades.pdf. 
13. Fleisher, C. S. \& Bensoussan, B. E. (2007). Business and Competitive Analysis Effective Application of New and Classic Methods.Singapore: Financial Time Press.

14. Government of Newfoundland and Labrador, "Strategic planning facilitator guide," Gastrointest. Endosc., vol. 40, no. 2 Pt 1, pp. 254-255, 2005, [Online]. Available: http://www.ibrd.gov.nl.ca/ regionaldev/StratPlanGuide.pdf.

15. Hai, H-L. and Tsou, M-C. (2009). Strategic development for the department of information management of Shih Chien University Kaohsiung Campus in Taiwan by a quantifiable SWOT analysis.Journal ofInformation \& Optimization Sciences, 30(1), 87-99.

16. Hayati, K. \& Unik, A. (2008). Perencanaan Strategik Universitas Lampung Dalam Perspektif Balanced Scorecard. Jurnal Bisnis \& Manajemen, 4(3), 267-282.

17. Kamayuda, D. M. D., \& Krismanda, M. A. (2016). Perencanaan Strategi Bersaing Sekolah Dalam Meningkatkan Mutu Pendidikan Di Sekolah Swasta Salatiga. Satya Widya, 32(2), 79-91.

18. Kuiper, S. and Thomas, M.W. (2000). A strategic Consultancy Model for Establishing a Center for Business Communication. Business Communication Quarterly. 63(2), 52-67.

19. Lane, R. J., Bishop, H. L., \& Wilson-Jones, L. (2013). Creating an Effective Strategic Plan for the School District. Journal of Instructional Psychology. 32 (3) 197-204.

20. Lerner, A. L. (1999). Strategic Planning for Higher Education. The Journal of Higher Education, 52(5), 470.

21. Lingam, G, Lingam N, \& K. Raghuwaiya K. (2014). Effectiveness of School Strategic Planning: The Case of Fijian Schools. World Academy of Science, Engineering and Technology, 8(7), 2119-2125.

22. Linn, M. (2008). Planning Strategically and Strategic Planning. The Bottom Line: Managing Library Finances, 21(1), 20-23.

23. Lumby, J. (1999). Strategic Planning in Further Education: The business of values. Educational Management Administration and Leadership, 27(1), 71-83.

24. Helms, M. M., \& Nixon, J. (2010). Exploring SWOT analysis - where are we now? A review of academic research from the last decade. In Journal of Strategy and Management 3(3) 215 - 251.
25. McNamara, C. (2006). Basic Overview of Various Strategic Planning Models. http://www.managementhelp.org/plan_dec/s tr_plan/models.htm.

26. McNamara, C. (2011). "All about Strategic Planning". Free Management Library: http://managementhelp.org/strategicplannin g/indexhtm\#anchor 1234

27. McNamara, C. "Field Guide to Nonprofit Strategic Planning and Facilitation," p. 284, 2007, [Online]. Available: http://books.google.com/books?id=pjXTNA AACAAJ\&pgis $=1$.

28. Masakim, A., Nizwardi J., Fahmi R. (2012). "Evaluasi Dan Pengembangan Model Rencana Strategis SMK Negeri 1 Batam" Thesis. Universitas Negeri Padang

29. Mulayasa, H. E. 2007. Manajemen Berbasis Sekolah, Konsep, Strategi dan Implementasi. Bandung: Remaja Rosdakarya

30. Musnandar, A. (2013). Dalam Pengembangan Budaya Organisasi Pada Perguruan Tinggi Islam: Studi Kasus di UIN Maliki Malang, Ulul Albab14(1), 57-84.

31. Ni Luh, Putu, H. 2013. Perencanaan Manajemen Strategis dalam Meningkatkan Kualitas Pendidikan di Sekolah Menengah Atas Negeri. ITATS Surabaya. 14(23) 960962.

32. Nurdin, N. (2008). Strategi Manajemen Mutu Pada SMA Negeri Unggulan Di Kota Bandung. Jurnal Administrasi Pendidikan UPI, 7(1):

33. Peraturan Pemerintah Republik Indonesia Nomor 19 Tahun 2005 tentang Standar Nasional Pendidikan. http://pelayanan.jakarta.go.id/download/reg ulasi/

34. Peraturan Menteri Pendidikan Nasional Nomor 19 Tahun 2007 tentang Standar Pengelolaan Pendidikan. http://pelayanan.jakarta.go.id/download/

35. Pisel, K. P. (2001). The validation of a detailed strategic planning process model for the implementation of distance education in higher education. The American Journal of Distance Education, 3 (1), 4-19

36. Remiasa, M. (2005). Perencanaan Strategis Pemasaran Untuk Menciptakan Sustainable Competitive Advantage (Kasus Pada Program Studi Manajemen Perhotelan UK Petra di Surabaya). Jurnal Manajemen Perhotelan, 1 (1) 14-23. 
37. Restusari, A. (2017). Manajemen Strategik Dalam Peningkatan Mutu Guru Di Mts Negeri Model Purwokerto Kabupaten Banyumas. Thesis. Pascasarjana Institut Ilmu Agama Islam Negeri Purwokerto.

38. Rindaningsih, I. (2012). Pengembangan Model Manajemen Strategik Berbasis (Beyond Center and Circle Time) BCCT Pada Paud. Pedagogia. 1(2), 213-223.

39. Schraeder, M. (2002). A Simplified Approach to Strategic Planning: Practical Considerations and an Illustrated Example. Business Process Management Journal, 8(1), 8-18.

40. Susanto, A.J. (2005). Formulasi Strategi Pengembangan Sekolah Menengah Atas Negeri 1 Jepara di Kabupaten Jepara. Thesis. Pasca Sarjana Universitas Diponegoro.
41. Syahrul. (2017). Perencanaan Strategis dan Praktiknya di Perguruan Tinggi. Shautut Tarbiyah, (36) XXIII, 1-18.

42. Undang-Undang Republik Indonesia Nomor 25 Tahun 2004tentang sistem perencanaan pembangunan nasional. Jakarta, dari http://www.dpr.go.id/dokjdih/ document/uu/26.pdf.

43. Wyk, Van C. \& Moeng, B. G. (2014). The Design And Implementation Of A Strategic Plan In Primary Schools, International Business \& Economics Research Journal13(1), 137-145.

How to cite this article: Fransiskus Z. M. Deidhae, Masrukhi, Hardyanto W et.al. Analysis of school strategic planning practices. International Journal of Research and Review. 2021; 8(8): 106-115. DOI: https://doi.org/10. 52403/ijrr.20210816 